\title{
Craniofacial injuries in Brazilian women victims of aggression
}

\author{
Lesões craniofaciais em mulheres brasileiras vítimas de agressão \\ Lesiones craneofaciales en mujeres brasileñas víctimas de agresión \\ Liz Lider Maggi CÁRDENAS ${ }^{1}$ \\ Isabella Lima Arrais RIBEIRO \\ Gabrielle Stella Dantas BARBOSA ${ }^{3}$ \\ Ricardo Dias de CASTRO ${ }^{4}$ \\ Paloma Rodrigues GENÚ 5 \\ ${ }^{1}$ Specialist in Forensic Dentistry, Sete Lagoas College, 58053-012 João Pessoa- Paraíba, Brazil \\ ${ }^{2}$ Post-Doctorate in Epidemiology, Graduate Program in Dentistry, Federal University of Paraíba, \\ 58053-012 João Pessoa-PB, Brazil \\ ${ }^{3}$ Dentistry Student, João Pessoa University Centre, 58053-012, João Pessoa-PB, Brazil \\ ${ }^{4}$ Adjunct Professor in the Graduate Program in Dentistry, Federal University of Paraíba, \\ 58053-012 João Pessoa-PB, Brazil \\ ${ }^{5}$ Master's, PhD and Specialization in Oral-Maxillofacial Surgery and Traumatology and Dental Implants, \\ 50740-600, Recife-PE, Brazil
}

\begin{abstract}
Objective: To characterize craniofacial injuries in Brazilian women who were victims of violence in 2005 and 2015. Methods: Descriptive and retrospective study with data collected from records of victims with craniofacial injuries from the forensic medicine institute of a Brazilian city with a large population. The following information was recorded: age, civil status, degree of aggressor kinship, location of the injury and type of instrument used in the aggression. The data were analysed using IBM SPSS (21.0), and a 5\% significance level was adopted. Main results: A total of 962 records were assessed, including 481 from 2005 and 481 from 2015. When 2005 and 2015 were compared, an increase in the number of records of victims in the age range 31 years and above was found, with the largest number of records related to victims 51 to 60 years old (38.48\%). The intraoral region and hard tissues were significantly more affected in 2015 than in 2005 ( $\mathrm{p}<0.001$ ). Conclusions: No changes in the numbers of aggression victims were observed between 2005 and 2015. After the approval of the Maria da Penha Law, aggression were focused more on age ranges older than 31 years. The number of aggression perpetrated by first-degree relatives was greater in 2015 than in 2005, as was the number of injuries to the intraoral region and hard tissues.
\end{abstract}

Descriptors: Violence Against Women; Wounds and Injuries; Forensic Medicine; Domestic Violence.

\section{Resumo}

Objetivo: Caracterizar lesões craniofaciais em mulheres brasileiras vítimas de violência em 2005 e 2015. Métodos: Estudo descritivo e retrospectivo com dados coletados de prontuários de vítimas com lesões craniofaciais do Instituto de Medicina Legal de uma cidade brasileira com grande população. Foram registradas as seguintes informações: idade, estado civil, grau de parentesco do agressor, localização da lesão e tipo de instrumento utilizado na agressão. Os dados foram analisados utilizando-se o IBM SPSS $(21,0)$, adotando-se um nível de significância de 5\%. Resultados principais: Foram avaliados 962 registros, dos quais 481 de 2005 e 481 de 2015. Quando comparados os anos de 2005 e 2015, verificou-se um aumento no número de registros de vítimas na faixa etária de 31 anos ou mais, sendo a maior Número de registros relacionados às vítimas de 51 a 60 anos (38,48\%). A região intraoral e os tecidos duros foram significativamente mais afetados em 2015 do que em 2005 ( $(p<0,001)$. Conclusões: Entre 2005 e 2015 não foram observadas alterações no número de vítimas de agressão. Após a aprovação da Lei Maria da Penha, a agressão se concentrou mais nas faixas etárias acima de 31 anos. O número de agressões perpetradas por parentes de primeiro grau foi maior em 2015 do que em 2005, assim como o número de lesões na região intraoral e tecidos duros. Descritores: Violência contra a Mulher; Ferimentos e Lesões; Medicina Legal; Violência Doméstica.

\section{Resumen}

Objetivo: Caracterizar lesiones craneofaciales en mujeres brasileñas víctimas de violencia en 2005 y 2015. Métodos: Estudio descriptivo y retrospectivo con datos recolectados de registros de víctimas con lesiones craneofaciales del Instituto de Medicina Legal de una ciudad brasileña con gran población. Se registró la siguiente información: edad, estado civil, grado de parentesco del agresor, ubicación de la lesión y tipo de instrumento utilizado en la agresión. Los datos se analizaron utilizando IBM SPSS (21.0), y se adoptó un nivel de significación del 5\%. Resultados principales Se evaluaron un total de 962 registros, de los cuales 481 de 2005 y 481 de 2015. Cuando se compararon los años 2005 y 2015, se encontró un aumento en el número de registros de víctimas en el rango de edad de 31 años y más, Número de registros relacionados con víctimas de 51 a 60 años $(38,48 \%)$. La región intraoral y los tejidos duros fueron significativamente más afectados en 2015 que en 2005 ( p <0,001). Conclusiones: No se observaron cambios en el número de víctimas de agresión entre 2005 y 2015. Tras la aprobación de la Ley Maria da Penha, la agresión se centró más en los grupos de edad de más de 31 años. El número de agresiones perpetradas por parientes de primer grado fue mayor en 2015 que en 2005, así como el número de lesiones en la región intraoral y los tejidos duros.

Descriptores: Violencia contra la Mujer; Heridas y Lesiones; Medicina Legal; Violencia Doméstica.

\section{INTRODUCTION}

Situations of violence constitute a complex set of complaints that affect a growing number of individuals of all ages and genders. These situations are considered a serious public health problem in Brazil ${ }^{1}$. Until the 1980s, there were no or few public policies in the country geared towards women's rights. This situation began to change in 1984 when Brazil ratified the Convention on the Elimination of All Forms of Discrimination against Women (CEDAW), which acknowledged that discrimination against women violated the principles of equal rights and the respect of human dignity; hindered the participation of women in the political, social, economic and cultural life of their country; 
and constituted an obstacle to increased welfare of the society and family ${ }^{2}$. According to Pasinato and Santos ${ }^{3}$, police stations specializing in crimes against women emerged in response to feminist demands in 1985 in São Paulo.

Violence practiced against women is generally based on vulnerability and can manifest through any action or omission that causes the woman's death; injury; physical, sexual or psychological suffering; or moral or property damage. Gender violence and violence against women are terms used to name this serious problem ${ }^{4}$. The health sector plays an important role in combating this type of violence through the development of research, notification of cases, and organization of reference services for victims and other types of interventions. However, no strategy for combating violence can avoid addressing the cultural roots of these abuses, and these strategies must also meet the immediate needs of the victims 5 .

The Brazilian law that specifically protects women against violence (Law 11,340 of August 7, 2006, known as the Maria da Penha Law) proposes mechanisms to curb and prevent domestic and family violence against women in the terms of article $226 \S 8$ of the Federal Constitution and other international treaties ratified by the Federative Republic of Brazil. The Law also created Courts of Domestic and Family Violence against Women and established means for the assistance and protection of women in domestic and family violence situations. All women, regardless of race, ethnicity, sexual orientation, income, culture, education level, age or religion, have fundamental rights inherent to all humans and are guaranteed opportunities and means to live without violence and to preserve their physical and mental health and their moral, intellectual and social improvement. The Maria da Penha Law incorporated the international legislative progress and became the main legal instrument protecting women against violence in Brazil, putting into effect the constitutional provision that required the State to ensure "assistance to the family and each of its members, in the context of their relationships"6.

Although violence against women is of interest to researchers in Latin America, there are no definitive answers about the nature and causes of the problem ${ }^{7}$. It is estimated that the number of non-notified cases of violence against women practiced by an intimate partner is significant. Factors such as fear of the attacker and societal shame cause these women to not report their companions. Additionally, many women do not recognize the situation experienced as violence ${ }^{8}$.

Barbieri $^{9}$ calls attention to the importance of the contribution of dentists to judicial swiftness, forensic accuracy, scientific research and the defence of citizens when these professionals are present in the evaluation of the extent and severity of injuries or in the investigation of cases of violence against women involving injuries to the head and neck. Additionally, dentists can make alerts based on these cases to other professionals in the dentistry area to identify potential female victims of aggression. The involvement of Dentistry in studies of complex oral-maxillofacial injuries becomes essential for both the diagnosis and the attempt to repair the damage because physical violence leads to the death of thousands of people, as shown by data from different Forensic Medicine Institutes ${ }^{10}$.

Regarding injuries and injury sites, the head and neck region is the most prevalent in this type of occurrence ${ }^{11-13}$ The face, which is a very vulnerable region due to its peculiarities and anatomical and functional complexity, is frequently traumatized, requiring special attention from health professionals. Additionally, the face has importance due to its structures in society and interpersonal relationships ${ }^{14-16}$. Violent injury to the face is not limited to visible lesions or lesions without functional loss and, depending on the extent of the injury, can involve the brain, eyes, maxillary sinuses and teeth in addition to soft tissues and bones ${ }^{14-17}$.

The aim of the present study was to quantify, qualify and compare the aggressions recorded in the exams of craniofacial injuries in women who were victims of violence in the Forensic Medicine Department of João Pessoa, Paraíba (PB), Brazil, one year before (2005) and 10 years after (2015) the Maria da Penha Law was ratified. We sought to determine whether there was a significant difference between the numbers of aggressions between the two years, to discriminate the types of injuries most frequently encountered and to identify the most commonly affected anatomical regions. Additionally, we grouped the victims according to age, civil status, profession and degree of kinship with the attacker and identified the most commonly injured regions of the face and the type of object that caused the injuries in each year (2005 and 2015).

\section{MATERIAL AND METHODS}

The present retrospective, descriptive and longitudinal study was approved by the Committee on Ethics in Human Research (CAAE: 55885216.2.0000.5176).

The study was conducted in the city of João Pessoa, $\mathrm{PB}$, Brazil. Data were collected from the all forensic exam records of women who were victims of facial injuries and who were referred by police stations and/or other responsible bodies to the Forensic Medicine Department of João Pessoa due to gender violence in 2005 and 2015.

The data were collected by filling out a standardized form. Then, the data were entered into a Microsoft Excel.

The form designed for the study contained the following information:

a) For the victims: age, occupation, civil status and degree of kinship to the attacker.

b) For the injury site (skull and face): extraoral or intraoral and soft tissue or hard tissue (skull bones, cheekbones and dental elements).

c) For the type of injury: dental (concussion, avulsion, luxation or fracture), mandibular (dislocation or fracture), bones of the skull or face (fractures), mouth opening limitation, bite marks, lacerations, hematoma, oedema, ecchymosis and scratches.

d) For the weapon type (instruments): blunt, sharp, perforating, blunt-sharp, perforating-sharp and not informed.

\section{- Data Analysis}

The data were analysed for descriptive and inferential statistics in IBM SPSS (21.0). The Shapiro-Wilk normality test was used to test the normality of the data regarding the number of aggressions. The distribution of these data was found to be non-normal $(\mathrm{p}=0.004)$. The Mann-Whitney test was used to compare the mean number of aggressions in each year included in the study. The Chi-square test was used to assess significant differences between the frequency distributions of the victims regarding the variables of interest. For all tests, we adopted a 5\% significance level.

\section{RESULTS}

In 2005 and 2015, there were 481 and 481 aggressions against women, respectively. The mean 
( \pm standard deviation) and median ages of the battered women were 40.00 years $( \pm 6.39)$ and 40.00 years in 2005 and 40.08 years $( \pm 10.88)$ and 39.00 years in 2015, respectively. According to the Mann-Whitney test, there were no significant differences in the total number of aggressions between 2005 and $2015(\mathrm{p}=0.551)$. The data regarding violence against women in João Pessoa in 2005 and 2015 are described in Tables 1, 2 and 3.

The Table 1 shows a significant difference between the years studied regarding the age ranges affected by gender violence. There was a reduction in the number of aggressions in the 10 to 30 years age range and an increase in the number of aggressions against women 31 years and older. An increase of $38.48 \%$ was observed in the 51 to 60 years age range, and a decrease of $12.14 \%$ was observed in the 21 to 30 year age range. Furthermore, there was a predominance of single women in the two years studied. The number of victims who reported being married (or in a stable union) increased by $21.48 \%$. There was a difference in the number of divorced victims, which exhibited a $22.28 \%$ increase between the years. Additionally, there was a $22.24 \%$ increase in the number of aggressions perpetrated by 1 st degree relatives in 2015 compared with 2005. The number of aggressions where the attacker was not related to the victim decreased by $14.28 \%$.

The Tables 2 and 3 contains, respectively, the results for the distribution for aggression victims, according the site and the injury.

Table 1. Distribution of Brazilian aggression victims in 2005 and 2015 according to age range, civil status and kinship to the attacker. João Pessoa, PB, Brazil, 2005 and $2015\left(\mathrm{n}=481\right.$ and $\mathrm{n}=481$, respectively $\left.{ }^{\mathrm{I}}\right)$

\begin{tabular}{cccccccc}
\hline Variable & \multicolumn{2}{c}{$\mathbf{2 0 0 5}$} & \multicolumn{2}{c}{$\mathbf{2 0 1 5}$} & \multicolumn{2}{c}{ Total } & Sig. \\
\hline Age range & $\mathbf{n}$ & $\mathbf{( n = 4 4 8 )}$ & $\mathbf{n}$ & $\mathbf{( n = 4 6 8 )}$ & $\mathbf{n}$ & $\mathbf{\%}$ & \\
10 to 20 & 111 & $55.77 \%$ & 88 & $44.23 \%$ & 199 & $100 \%$ & \\
21 to 30 & 180 & $56.07 \%$ & 141 & $43.93 \%$ & 321 & $100 \%$ & \\
31 to 40 & 98 & $41.88 \%$ & 136 & $58.12 \%$ & 234 & $100 \%$ & $0.032^{*}$ \\
41 to 50 & 42 & $37.83 \%$ & 69 & $62.17 \%$ & 111 & $100 \%$ & \\
51 to 60 & 12 & $30.76 \%$ & 27 & $69.24 \%$ & 39 & $100 \%$ & \\
61 to 70 & 5 & $41.66 \%$ & 7 & $58.34 \%$ & 12 & $100 \%$ & \\
Civil status & $(\mathbf{n = 3 0 8})$ & & $(\mathbf{n}=\mathbf{3 5 9})$ & & & & \\
Single & 218 & $49.77 \%$ & 220 & $50.23 \%$ & 438 & $100 \%$ & \\
Stable union & 75 & $39.26 \%$ & 116 & $60.74 \%$ & 191 & $100 \%$ & $0.001^{*}$ \\
Divorced & 10 & $38.46 \%$ & 16 & $60.74 \%$ & 26 & $100 \%$ & \\
Widowed & 5 & $41.66 \%$ & 7 & $58.34 \%$ & 12 & $100 \%$ & \\
Kinship & $(\mathbf{n = 4 8 0})$ & & $(\mathbf{n = 4 8 1})$ & & & & \\
$1^{\text {st }}$ degree relative & 21 & $38.88 \%$ & 33 & $61.12 \%$ & 54 & $100 \%$ & \\
$2^{\text {nd }}$ degree relative & 7 & $41.17 \%$ & 10 & $58.83 \%$ & 17 & $100 \%$ & \\
Partner & 158 & $45.79 \%$ & 187 & $54.21 \%$ & 345 & $100 \%$ & $0.036^{*}$ \\
Former partner & 62 & $44.60 \%$ & 77 & $55.40 \%$ & 139 & $100 \%$ & \\
No relation & 232 & $57.14 \%$ & 174 & $42.86 \%$ & 406 & $100 \%$ & \\
\hline
\end{tabular}

Chi-square test, $\alpha=5 \%$. *Significant difference between years. Source: Research data $=$ The information of interest were not fully recorded for all victims.

Table 2. Distribution of Brazilian aggression victims in 2005 and 2015 according to the injury site. João Pessoa, PB, Brazil, 2005 and 2015

\begin{tabular}{lccccccc}
\hline \multicolumn{1}{c}{ Injury site } & \multicolumn{2}{c}{$\mathbf{2 0 0 5}$} & \multicolumn{2}{c}{$\mathbf{2 0 1 5}$} & \multicolumn{2}{c}{ Total } & Sig. \\
\hline Skull & $\mathbf{n}$ & $\mathbf{\%}$ & $\mathbf{n}$ & $\mathbf{\%}$ & $\mathbf{n}$ & $\%$ & \\
Face & 157 & $48.75 \%$ & 177 & $51.25 \%$ & 322 & $100 \%$ & \\
Extraoral & 386 & $51.74 \%$ & 360 & $48.26 \%$ & 746 & $100 \%$ & \\
Intraoral & 359 & $54.97 \%$ & 294 & $45.03 \%$ & 653 & $100 \%$ & $0.000^{*}$ \\
Soft tissue & 41 & $38.67 \%$ & 65 & $61.33 \%$ & 106 & $100 \%$ & \\
& 94 & $50.26 \%$ & 93 & $49.74 \%$ & 187 & $100 \%$ & \\
\hline
\end{tabular}

Chi-square test, $\alpha=5 \%$. *Significant difference between years.
Table 3. Distribution of Brazilian aggression victims in 2005 and 2015 according to the injury type. João Pessoa, PB, Brazil, 2005 and 2015

\begin{tabular}{lccccccc}
\hline \multicolumn{1}{c}{ Injury type } & \multicolumn{2}{c}{$\mathbf{2 0 0 5}$} & \multicolumn{2}{c}{$\mathbf{2 0 1 5}$} & \multicolumn{2}{c}{ Total } & Sig. \\
\hline Edema & $\mathrm{n}$ & $\%$ & $\mathrm{n}$ & $\%$ & $\mathrm{n}$ & $\%$ & \\
Concussion & 136 & $44.29 \%$ & 171 & $55.71 \%$ & 307 & $100 \%$ & \\
Hematoma & 0 & $0.00 \%$ & 6 & $100.00 \%$ & 6 & $100 \%$ & \\
Ecchymosis & 19 & $32.75 \%$ & 39 & $67.25 \%$ & 58 & $100 \%$ & \\
Fracture & 1 & $54.39 \%$ & 166 & $45.61 \%$ & 364 & $100 \%$ & \\
Scratch & 125 & $33.33 \%$ & 2 & $66.67 \%$ & 3 & $100 \%$ & $0.000^{*}$ \\
Avulsion & 0 & $0.00 \%$ & 1 & $100.00 \%$ & 1 & $100 \%$ & \\
Bite & 2 & $66.67 \%$ & 1 & $33.33 \%$ & 3 & $100 \%$ & \\
Bulging & 1 & $100.00 \%$ & 0 & $0.00 \%$ & 1 & $100 \%$ & \\
\hline
\end{tabular}

Chi-square test, $\alpha=5 \%$. *Significant difference between years.

\section{DISCUSSION}

According to the Brazilian government, one in every five Brazilians have experienced domestic violence committed by a man, $56 \%$ of Brazilian women and men know a man who has battered a partner, and 54\% know at least one woman who has suffered some type aggression from a partner ${ }^{18}$

In this study, approximately $80 \%$ of the cases of violence against Brazilian women were committed by partners or ex-partners. Costa et al. ${ }^{19}$ found that $69.46 \%$ of aggressions were practiced by the current partner $(28.61 \%$ by the spouse, $38.75 \%$ by the partner and $2.10 \%$ by the boyfriend) and $24.38 \%$ by the former partner ( $16.66 \%$ by the former partner, $3.61 \%$ by the former spouse and $4.11 \%$ by the former boyfriend), for a total of more than $90 \%$ of cases. The present study agreed with these findings because a total of $43.83 \%$ of the aggressions in 2005 and $57.13 \%$ in 2015 were performed by the partner or former partner. This finding suggests that this change is a positive effect of the Maria da Penha Law, which attempts to inhibit the action of those who see women as "objects" that they own in sexist and patriarchal Brazilian society.

This law also includes cases that are independent of kinship: the attacker may be the stepfather/stepmother, father-in-law/mother-in-law, brother-in-law/sister-in-law or others, as long as the victim is a woman ${ }^{5}$. Based on the analysis of the type of kinship between the victim and the aggressor, the $4.38 \%$ of attacks by first-degree relatives observed in 2005 increased to $6.27 \%$ in 2015 . For seconddegree relatives, the $1.87 \%$ of attacks observed in 2005 exhibited a small variation to $1.94 \%$ in 2015 . A lack of a blood relationship with the victim accounted for $46.34 \%$ of the cases in 2005 and $37.66 \%$ in 2015.

Brazilian official data highlighted that young women were the main victims, with $31 \%$ in the 20 to 29 year and $23 \%$ in the 30 to 39 years age ranges ${ }^{20}$. Data collected from police reports in 2006 (the year the Maria da Penha Law was implemented) showed an incidence of $70.38 \%$ of women in the 20 to 40 years age range ${ }^{19}$. The present study indicated that women aged between 21 to 30 years accounted for $37.57 \%$ of the victims in 2005 ; this percentage decreased to $29 \%$ in 2015 . There was also a considerable increase in the number of cases in the 31 to 70 years age range, with $38.48 \%$ of the victims aged between 51 and 60 years.

According to the Brazilian government, most of the victims had low education levels (up to 8 years of study) and were aged 15 or more years $(48 \%)^{20}$. The study conducted by Costa et al. ${ }^{19}$ revealed that $51 \%$ of women reported being homemakers (i.e., performed only work related to the domestic care of their own homes and families). A total of 
$7.93 \%$ were students, and $3.82 \%$ were retired. One of the limitations of the present study was the lack of information collected in the records from the responsible bodies or from the Forensic Medicine Department itself. For example, the victim's profession was only reported in $18.91 \%$ of the records from 2005 and $8.8 \%$ of the records from 2015. Thus, the filling out of records, police reports and reports from the Legal Medical Institute has a preponderant role for the results of statistical analyses. Moreover, according to article 299 of the Penal Code, incorrect, incomplete, false or nonexistent information in the report regarding facts related to the patient may characterize fraudulent misrepresentation: omitting, in public or private documents, a statement that the document should contain or entering (or making it be entered) a false statement or a statement that deviates from that which should be written to hinder rights, create obligations or alter the truth about a legally relevant fact $(\ldots)^{21}$.

Regarding the civil status declared by the victims, there was a predominance of single women in 2005 and 2015. Data from a Women's Reference Centre in the same city in which the present study was performed showed that in $2015,27 \%$ of battered women declared being single, $52 \%$ were married or in a stable union, $12 \%$ were separated or divorced, $2 \%$ were widowed, and $3 \%$ did not provide information concerning their civil status. Women were considered married only when they had contracted a civil marriage $^{19}$. In the present study, there was an increase of $22.28 \%$ in the number of divorced victims. Records that did not specify the civil status of the victims accounted for $36.11 \%$ in 2005 and $25.46 \%$ in 2015 .

In the study of Costa et al. ${ }^{19}$, which used geoprocessing for the year 2006 in João Pessoa, a total of 508 police reports were available in the Women's Police Station during the period studied, with the monthly incidence estimated at 42 cases per month. The present study found that in 2005 (one year before Law 11.340/06 was enforced), there were 481 records of victims with injuries to the skull and face in a 12-month period. Considering the same injury sites, in 2015, there was no change in the number of cases, with the mean of 40.08 cases/month maintained.

The number of homicides against women increased by $260 \%$ over the ten-year period according to the Violence Map 2015 - Homicide against Women in Brazil released in November 2015. This map analysed violence data between 2003 and 2013 throughout the country and reported that the number of homicides increased from 35 in 2003 to 126 in 2013. However, the incidence rate of the crime dropped slightly between 2011 and 2013, decreasing from 7.2 to 6.4 deaths per 100,000 inhabitants. Regardless, the mean is still higher than the mean for Brazil of $4.8^{22}$.

The capital city of João Pessoa was the Brazilian capital with the third highest rate of homicides against women between 2003 and 2013 according to a survey conducted in the state of Paraíba, with 10.5 occurrences per 100,000 inhabitants. However, according to this survey, 48,245 women were battered by people known to them in Paraíba and another 22,366 were battered by people unknown to them in $2013^{22}$. These data justify the selection of this city for the performance of the present study.

There is an understanding that the Maria da Penha Law has a specific object (women) and a specific objective (safeguarding and protecting the rights of women) with constitutionality guaranteed by the Federal Constitution, which allows for "unequal treatment of unequals" (a situation in which women fall because of their vulnerability when subjugated due to gender) that cannot be undermined $^{4}$.

Violence is first and foremost a social phenomenon and is inherent to human life. The creation of laws by itself will not alter this fact but will contribute to punishing those who disregard the law, and through laws, victims can seek protection and a judicial response $\mathrm{e}^{20}$.

\section{CONCLUSION}

In conclusion, after the approval of the Maria da Penha Law in 2006, there were no significant changes in the number of victims of aggression, and the mean age of aggression victims and the total number of aggressions were the same in 2005 and 2015. There was a difference between 2005 and 2015 in the number of aggressions per age range, with aggressions against women aged 41 years and older more common in 2015. More women in a stable union and divorced women were battered in 2015 compared to 2005 .

Additionally, in 2015, aggressions were primarily perpetrated by $1^{\text {st }}$ degree relatives. The intraoral region and hard tissues were significantly more affected in 2015 than in 2005; ecchymosis was the most prevalent injury type and was predominantly caused by blunt instruments.

\section{REFERENCES}

1. Santos CM, Izumino WP. Violência contra as mulheres e violência de gênero: notas sobre estudos feministas no Brasil. EIAL. 2005; 16(1):147-64.

2. Alves FM. Lei Maria da Penha: das discussões à aprovação de uma proposta concreta de combate à violência doméstica e familiar contra a mulher. Jus Navigandi. 2006. Available in: <http://jus2.uol. com.br/doutrina/texto.asp?id=8764>. Accessed in 2016 Mar 13.

3. Pasinato W, Santos CMD. Mapeamento das Delegacias da Mulher no Brasil. Núcleo de Estudos de Gênero Pagu. Universidade Estadual de Campinas. 2008. Available in: <http://www.observe.ufba.br/_ARQ /bibliografia/MAPEO_Brasil \%5B1 \%5 D.pdf. 2014>. Accessed in 2016 Mar 11.

4. Brasil. Lei n. 11.340, de 7 de agosto de 2006. Cria mecanismos para coibir a violência doméstica e familiar contra a mulher e dá outras providências. Diário Oficial da União, 2006. Seção 1, p. 1.

5. Audi CAF, Segall-Corrêa AM, Santiago SM, Andrade MGG, Pèrez-Escamila R. Violência doméstica na gravidez: prevalência e fatores associados. Rev Saúde Pública. 2008; 42(5):877-85.

6. Direito Net. A eficácia da Lei Maria da Penha. 2014. Available in: <http//www.direitonet.com.br/artigos/ exibir/8757/A-eficacia-da-Lei-Maria-da-Penha>.

Accessed in 2016 Mar 13.

7. Castro R, Riquer F. La investigación sobre violencia contra las mujeresen América Latina: entre el empirismo ciego y lateoríasindatos. Cad Saúde Pública. 2003; 19(1):135-46.

8. Schraiber LB, Oliveira AFPLD, Junior IF, Diniz S, Portella AP, Ludemir AB. Prevalência da violência contra a mulher por parceiro íntimo em regiões do Brasil. Rev Saúde Publica. 2007; 41(5):797-809.

9. Garbin CAS, Garbin AJI, Dossi AP, Dossi MO. Violência doméstica: análise das lesões em mulheres. Cad Saúde Pública. 2006; 22(12):2567-73. 
10. Brasil. Ministério da Saúde. Norma técnica: Prevenção e tratamento dos agravos resultantes da violência sexual contra mulheres e adolescentes. 2. ed. Brasília: Secretaria de Políticas da Saúde, 2002.

11. Winzer L. Frequency of self-reported sexual aggression and victimization in Brazil: a literature review. Cad Saúde Pública. 2016; 32(7): e00126315.

12. Dossi AP, Saliba O, Garbin CAS, Garbin AJI. Perfil epidemiológico da violência física intrafamiliar: agressões denunciadas em um município do Estado de São Paulo, Brasil, entre 2001 e 2005. Cad Saúde Pública. 2008; 24(8): 1939-52.

13. Garbin CAS, Garbin AJI, Dossi AP, Dossi MO Violência doméstica: análise das lesões em mulheres. Cad Saúde Pública 2006; 22(12):2567-73.

14. Roselino LMR, Bregagnolo LA, Pardinho MABS, Chiaperini A, Bérgamo AL, Santi LN. Danos bucomaxilo-faciais em homens da região de Ribeirão Preto (SP) entre 1998 e 2002. Odontologia, Ciência e Saúde. Rev CROMG. 2009; 10:71-7.

15. Dias IJ, Santiago BM. Violência de gênero contra a mulher: perfil de registros periciais da gerência executiva de Medicina e Odontologia Legal (GEMOL)João Pessoa/PB. Rev bras ciênc saúde. 2015; 18(4):315-24

16. Montovani JC, Campos LMP, Gomes MA, Moraes VRS, Ferreira FD, Nogueira EA. Etiologia e incidência das fraturas faciais em adultos e crianças: experiência em 513 casos. Rev Bras Otorrinolaringol. 2006; 72(2):235-41.

17. Flores YYR. La violencia contra mujeres en comunidades transnacionales de San Luis Potosí, México: un problema de salud pública. Cad Saúde Pública. 2016; 32(7): e00022115.

18. Núcleo Especializado de Promoção e Defesa dos Direitos da Mulher. Coordenadoria de Comunicação Social e Assessoria de Imprensa. Defensoria Pública do Estado de São Paulo. 2016. Available in: < http://www.defensoria.sp.gov.br/dpesp/Default.aspx?idP agina $=3355>$. Accessed in 2016 Jun 21.

19. Costa DCS, Lucena KDT, Silva ATMC, Moraes RM. Incidência da Violência Doméstica na Saúde de Mulheres no Município de João Pessoa/PB utilizando Geoprocessamento para o ano de 2006. UFPB. 2015. Available in: < http://www.de.ufpb.br/ mds/ Artigos_Web/ERMAC094.pdf $>$. Accessed in 2016 Abr 03.

20. Paula A. Lei Maria da Penha. Tribuna Popular online. 2014. Available in: http://www.jtribunapopular.com.br artigo/artigo-cientifico-lei-maria-da-penha\#. Accessed in 2016 Mar 13.

21. Brasil. Presidência da república. Casa Civil Subchefia para Assuntos Jurídicos. Decreto lei n. 2.848, de 7 de dezembro de 1940. 2016. Available in: http://www.planalto.gov.br/ccivil_03/decretolei/Del2848compilado.htm. Accessed in 2016 Mar 5.

22. Paraíba. Paraíba tem $2^{\circ}$ maior crescimento de homicídio de mulheres, diz pesquisa. [accessed in 2016 Mar 15]. 2015. Available in: http://g1.globo.com/pb/ paraiba/noticia/ 2015/11/paraiba-tem-2-maiorcrescimento-de-homicidio-de-mulheres-dizpesquisa.html. Accessed in $2016 \mathrm{Jul} 18$.

\section{CONFLICTS OF INTERESTS}

The authors declare no conflicts of interests.

\section{CORRESPONDING AUTHOR}

Isabella Lima Arrais Ribeiro

isabella_arrais@yahoo.com

Received 03/05/2017

Accepted 14/06/2017 